\section{Nutritional Status of Children Under 5 Years in Tribal Villages of Bastar Chhattisgarh India}

\author{
Teeku Sinha ${ }^{1 *}$, Gajendra Singh ${ }^{2}$ and Urya $\mathrm{Nag}^{3}$ \\ ${ }^{1}$ Department of Community Medicine, Late B. R. K. M. Govt. Medical College, \\ Jagdalpur, Chhattisgarh, India \\ ${ }^{2}$ Public Health Specialist, IIHMR, Chhattisgarh, India
}

${ }^{3}$ State Program Manager, National Health Mission, Chhattisgarh, India

\begin{abstract}
\section{Background}

The problem of malnutrition among children of age less than 5 years can be used to determine the need for nutritional surveillance, nutritional care or appropriate nutritional intervention program in community. National Family Health Survey-4 (2015-16) data revealed $42.3 \%$ (Chhattisgarh- $39.6 \%$ ) of children under five years are stunted and $53.1 \%$ (Chhattisgarh-39.2\%) are under weight due to chronic under nutrition in rural area of Bastar. India accounts for more than 3 out of every 10 stunted children in the world.
\end{abstract}

\section{Objectives}

To assess the health and nutritional status of under 5 year children in the rural areas of Bastar.

\section{Material \& methods}

A community based cross-sectional study was conducted in village Dimrapal, Biringpal and Pandripani catchment area of RHTC Tokapal. Door to door survey conducted during the months of July-September 2017. Data was collected using predesigned semi structured questionnaire. Mother who has children under 5 years of age were interviewed. The anthropometric measurements categorization among children was done using World Health Organization (WHO) guidelines. Data was analyzed using Microsoft Excel 2010.

\section{Results}

Out of 140 children ( 55 boys and 85 girls) participated in study and around $40.7 \%$ children were found to be stunted 29 . $3 \%$ found

*Corresponding author: Teeku Sinha, HOD Department of Community Medicine, Late BRKM Govt. Medical College, Jagdalpur, Chhattisgarh, India, E-mail: teekusinha@gmail.com

Citation: Sinha T, Singh G, Nag U (2019) Nutritional Status of Children Under 5 Years in Tribal Villages of Bastar Chhattisgarh India. J intern Med Prim Healthcare 3: 007.

Received: September 30, 2019; Accepted: October 21, 2019; Published: October 28, 2019

Copyright: ( 2019 Sinha T, et al. This is an open-access article distributed under the terms of the Creative Commons Attribution License, which permits unrestricted use, distribution, and reproduction in any medium, provided the original author and source are credited. to have wasting and around $44.3 \%$ were found underweight.

\section{Conclusion}

The findings are in line of results from NFHS-4.Genuine and appropriate assessment of the children using a valid tool can help to eliminate this emerging problem of malnutrition among our future generations.

Keywords: Chhattisgarh; Stunting; Malnutrition; Underweight; WHO

\section{Introduction}

Global evidence suggests that undernutrition continues to affect millions of children. Maternal and child under nutrition, and unstimulating household environments contribute to deficits in children's development, health and productivity in adulthood. The nutritional status of the population has well-established, profound effects on health throughout the lifecycle and is closely associated with cognitive and social development, particularly in early childhood. Adequate nutrition is especially important in periods of rapid growth and development, i.e., during the first 1000 days of life and adolescence. Poor nutrition during pregnancy, infancy, childhood, and adolescence can result into stunted physical, mental and social development with lifelong consequences [1].

Nearly, half of all deaths in children under- 5 are can be attributed to undernutrition, translating into avoidable loss of about 3 million young lives globally each year [2]. Additional 165 million children with stunted growth have compromised cognitive development and physical capabilities with almost all cases occurring in developing countries [3]. India has a very high burden of childhood stunting as 61 million (37\%) of the 165 million stunted children aged under 5 years globally are Indian children [4].

India is home to almost half the tribal population of the world [5]. The Scheduled Tribe population of the country, as per the 2011 census, was 104 million, constituting $8.6 \%$ of the total population [6]. ST constitutes about $8.2 \%$ of the total population of the country. They live in difficult circumstances in hills, forests, and difficult-to-reach geographical areas with limited access to public services [7]. According to the Census of India 2011, only $14 \%$ of the Tribal population in rural areas have a source of drinking water within their premises and $22.6 \%$ households have toilet facility in their households. Extreme poverty, cultural habits, lack of formal education, challenges of geographical conditions, and natural disasters are related with poor nutrition and health of Tribal people.

The Rapid Survey of Children (RSOC), 2013-2014 conducted by the Department of Women and Child Development showed that $38.7 \%$ of under 5 children are stunted, $15.1 \%$ are wasted and $29.4 \%$ are underweight. National Family Health Survey -4 also presents the same case for Chhattisgarh which has high tribal population. Within State, stunting $(42.2 \%)$, wasting $(26 \%)$ and underweight $(43.8 \%)$ are highest among Scheduled Tribes (ST) children [8]. The situation is same in NFHS-3 also. 


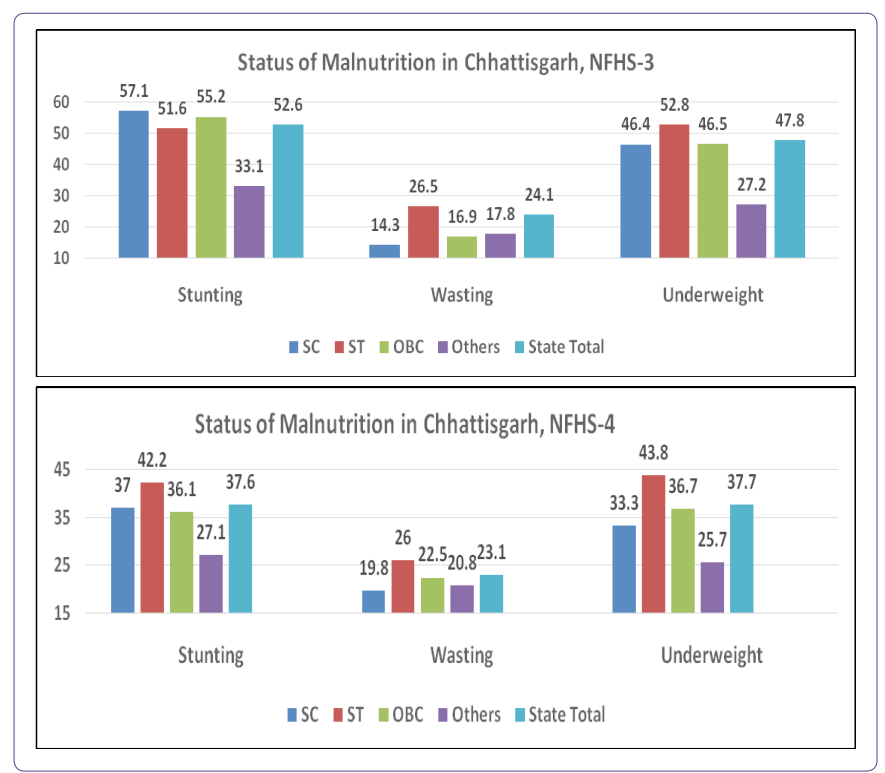

Malnutrition is a silent emergency [9]. It is frequently part of a vicious cycle that includes poverty and disease. These three factors are interlinked in such a way that each contributes to the presence and permanence of the others. Socioeconomic and political changes that improve health and nutrition can break the cycle; as can specific nutrition and health interventions. The health and social consequences of the current high prevalence of impaired child growth in developing countries are severe. The major outcomes of malnutrition during childhood may be classified in terms of morbidity, mortality, and psychological and intellectual development; there are also important consequences in adult life in terms of body size, work and reproductive performances, and risk of chronic diseases.

Several authors have examined the association between anthropometry and morbidity. The leading childhood diseases are diarrhoea, respiratory infections, measles, tuberculosis etc. It is known that a child may get affected several times in a year; the incidence increases with the aggravation of a state of malnutrition [10]. The three main indicators used to define under nutrition, i.e., underweight, stunting, and wasting, represent different histories of nutritional insult to the child. Occurring primarily in the first 2-3 years of life, linear growth retardation (stunting) is frequently associated with repeated exposure to adverse economic conditions, poor sanitation, and the interactive effects of poor energy and nutrient intakes and infection. Low weight-for-age indicates a history of poor health or nutritional insult to the child, including recurrent illness and/or starvation, while a low weight-for-height is an indicator of wasting (i.e., thinness) and is generally associated with recent illness and failure to gain weight or a loss of weight [11].

Deaths in children constitute more than $34 \%$ of total deaths in India [12]. Seven out of ten of these deaths are due to respiratory infections, Diarrhoea and malnutrition. There is high under five morbidity and mortality in India [13]. Protein energy malnutrition is major contributory factor in majority of these childhood morbidities and mortalities. At present $65 \%$ under five children are underweight which includes $47 \%$ moderate and $18 \%$ severe cases of malnutrition [14]. Protein calorie malnutrition is a widespread nutritional disease in developing countries [15]. Preschool (under five) children are notoriously fraught with the risk of malnutrition and the prevalence of malnutrition varies between $50-80 \%$ [16].

The three main indicators used to define under nutrition, i.e., underweight, stunting, and wasting, represent different histories of nutritional insult to the child. Occurring primarily in the first 2-3 years of life, linear growth retardation (stunting) is frequently associated with repeated exposure to adverse economic conditions, poor sanitation, and the interactive effects of poor energy and nutrient intakes and infection. Low weight-for-age indicates a history of poor health or nutritional insult to the child, including recurrent illness and/or starvation, while a low weight-for-height is an indicator of wasting (i.e., thinness) and is generally associated with recent illness and failure to gain weight or a loss of weight.

Undernutrition encompasses chronic malnutrition (stunting), acute malnutrition (wasting), and deficiencies of micronutrients. Undernutrition continues to remain the biggest cause of the global burden of disease. Specific programs are therefore designed to provide supplementary food for preschool-aged children and are a strategy towards responding to address this issue. In its seminal report published in 2006, UNICEF states "Undernutrition is the outcome of insufficient food intake and repeated infectious diseases. It includes being underweight for one's age, too short for one's age (stunted), dangerously thin for one's height (wasted), and deficient in vitamins and minerals (micronutrient malnutrition)".

\section{Objective}

As nutritional indicators are covered mainly through survey data (once in 3 years) and not so regular in administrative data of healthcare delivery, the directions of efforts are little away from reality. Also, the survey data for most of the indicators including those of nutrition are of up to district level so it's always good to disaggregated data as much as possible. With this idea, the primary objective of the study was "to assess the health and nutritional status of $<5$-year children in the rural areas of Bastar".

\section{Methodology}

The study was carried in permission with Institutional Ethics Committee of Govt. Medical College, Jagdalpur, and Chhattisgarh. A community based cross-sectional study was conducted in village Dimrapal, Biringpal and Pandripani catchment area of Rural Health Training Center (RHTC) Tokapal. Door to door survey conducted during the months of July-September 2017. Data was collected using predesigned semi structured questionnaire. All mothers who have children under 5 years of age were interviewed.

A semi-structured pretested interview schedule was used to collect information from the mother. In some cases (if mother was not available), information was collected from the caregiver. Weight and height were measured for all the selected children. Anthropometric measurements were carried out following standard methods. The data included weight, recumbent length (for children less than 24 months of age) and height (for children more than 24 months of age). Weight was measured using analog weighing machine Height was measured against a non-stretchable tape fixed to a vertical wall, with the participant standing on affirm/level surface and it was measured to the nearest $0.5 \mathrm{~cm}$. Recumbent length (for children less than 24 months 
Citation: Sinha T, Singh G, Nag U (2019) Nutritional Status of Children Under 5 Years in Tribal Villages of Bastar Chhattisgarh India. J intern Med Prim Healthcare 3: 007.

of age) was measured by using a measuring tape. All measurements were taken twice and the average of two readings was used for analysis. 0-5 year's children were taken for underweight and stunting in this study. Socioeconomic Status (SES) - was determined by using Modified Prasad's scale [17].

Based on the age, body weight and height, several indices such as height-for-age, weight-forage and weight-for-height have been suggested [18]. The children are classified using three categories:

- Underweight (low weight-for-age)

- Stunting (low height-for-age)

- Wasting (low weight-for-height)

Low anthropometric values are those more than 2 SD away from the Centers for Disease Control and Prevention (CDC) standards, $2000[19,20]$.

- Underweight is defined as low weight-for-age and it reflects past (chronic) and present (acute) under nutrition. Children with z-scores $<-2.00$ are said to be underweight

- Stunting is defined as a low height-for-age for children, and it measures the past (chronic) child under nutrition. Children with $\mathrm{z}$-scores $<-2.00$ are said to be stunted

- Wasting is defined as low weight-for-height for children, and it is a measure of current or acute under nutrition. Children with z-scores $<-2.00$ are said to be wasted

\section{Inclusion criteria \& Exclusion criteria}

All children under 5 years living in study field area (village Dimrapal, Biringpal and Pandripani) of RHTC Tokapal District Bastar were included in study. Children who were too unwell, agitated \& unwilling for anthropometric measurements were excluded from the study. Only 10 children were excluded because of above mentioned reasons. Children who were too unwell, agitated \& unwilling for anthropometric measurements were excluded from the study. Only 10 children were excluded because of above mentioned reasons (Tables 1-4).

\begin{tabular}{|c|c|c|c|}
\hline Age(months) & Males (\%) & Females (\%) & Total (\%) \\
\hline $0-12$ & $25.7(9)$ & $74.3(26)$ & $25.0(35)$ \\
\hline $13-24$ & $54.5(12)$ & $45.5(10)$ & $15.7(22)$ \\
\hline $25-36$ & $39.4(13)$ & $60.6(20)$ & $23.6(33)$ \\
\hline $37-48$ & $50.0(12)$ & $50.0(12)$ & $17.1(24)$ \\
\hline $49-60$ & $34.6(9)$ & $65.4(17)$ & $18.6(26)$ \\
\hline Total & $55(39.3)$ & $85(60.7)$ & $140(100)$ \\
\hline
\end{tabular}

Table 1: Age \& gender distribution of study population $(n=140)$.

Note: Table 1 shows age and gender distribution of study population. It was observed that out of total 140children, 55 (39.4\%) were males and 85 $(60.7 \%)$ were females. There were $35(25.0 \%)$ infants.

\section{Toilet and handwashing}

Only 4 families reported to have open defecation while none of the family reported to NOT to wash hands after defecation and feeding child. It's good to see this response as state is doing very fine in terms of Swachh Bharat Mission Swachh Bharat Abhiyan (SBA) or Swachh Bharat Mission (SBM) is a nation-wide campaign in India for the period 2014 to 2019 that aims to clean up the streets, roads and infrastructure of India's cities, towns, urban and rural areas. The campaign's official name is in Hindi and translates to "Neat and tidy India Mission" in English. The objectives of Swachh Bharat include eliminating open defecation through the construction of household-owned and community-owned toilets and establishing an accountable mechanism of monitoring toilet use. Run by the Government of India, the mission aims to achieve an "Open-Defecation Free" (ODF) India by 2 October 2019) [21].

\begin{tabular}{|c|c|c|}
\hline Occupation & Mother & Father \\
\hline Housewife & 97 & \\
\hline Labor & 3 & 23 \\
\hline Service & 20 & 43 \\
\hline Business & 2 & 18 \\
\hline Household Work & & 2 \\
\hline Farmer & & 42 \\
\hline Others & 18 & 12 \\
\hline Total & 140 & 140 \\
\hline
\end{tabular}

Table 2: Occupation of parents.

Note: Occupation of parents plays a major role in child nutrition. Majority of mothers were housewives and males were either farmer or in service.

\begin{tabular}{|c|c|c|}
\hline Education Status & Mother & Father \\
\hline Illiterate & 44 & 27 \\
\hline Up to $5^{\text {th }}$ & 31 & 22 \\
\hline Up to $8^{\text {th }}$ & 19 & 38 \\
\hline Up to $10^{\text {th }}$ & 26 & 18 \\
\hline Up to $12^{\text {th }}$ & 10 & 25 \\
\hline Graduation $^{\text {Post-Graduation }}$ & 8 & 7 \\
\hline Total & 140 & 3 \\
\hline
\end{tabular}

Table 3: Education Status of parents.

Note: Education status of parents is an important factor for nutrition among children. For 44 (31\%) children, both parents were having education status less than class 5 while for $25(18 \%)$ children both parents were illiterate.

\begin{tabular}{|c|c|c|l|}
\hline \multirow{2}{*}{ Type of Family } & No. of Members & No. of Members & Total \\
\cline { 2 - 4 } & $(<4)$ & $(>4)$ & \\
\hline Nuclear & 59 & 37 & 96 \\
\hline Joint & & 44 & 44 \\
\hline Total & 59 & 81 & 140 \\
\hline
\end{tabular}

Table 4: Type of Family and Family Size.

Note: Family size is an important aspect to be looked as it gives indirect hint to look at prospects of ensuring nutrition to child. 81 (58\%) families were having $>4$ members. Maximum family size was reported 8 in nuclear families and 11 in joint families.

\section{Age at Marriage and pregnancy}

Average age was 20.4 years with 19 (13.6\%) were having age 18 or less at time of marriage.24 (17\%) mothers were having age of less than 21 when they had this pregnancy (child for which anthropometric measures were taken) and $10 \%$ were having age more than 30 . 
Citation: Sinha T, Singh G, Nag U (2019) Nutritional Status of Children Under 5 Years in Tribal Villages of Bastar Chhattisgarh India. J intern Med Prim Healthcare 3: 007.

\section{Care around birth}

$113(80 \%)$ mothers reported receiving complete Antenatal care while no mother reported of not receiving Antenatal Care (ANC). $86 \%$ mothers received both Tetanus Toxoid (TT1 and TT2). Iron and Folic Acid (IFA) tablets were received by $86 \%$ mothers. $85 \%$ deliveries were reported to be institutional deliveries. Post-natal care is an issue as $74 \%$ mothers reported that they have not received any post-natal care.

\section{Nutritional and dietary practices}

Breastfeeding to newborn and colostrum administration was reported by $100 \%$ mothers which is a good practice. $93 \%$ mothers initiated breastfeeding immediately after birth or within one hour of birth. $90 \%$ mothers started supplementary feeding after age of 6 months. $82 \%$ families reported to have Non-vegetarian diet. 94\% families reported that females of family including girl child have food along with family rather than having left over food. All families wash vegetables before cooking them. $80 \%$ of mothers were having Non-vegetarian diets.

\section{Birth details and immunizations}

$80 \%$ of children were having birth order 1 or 2 . Birth weight of less than $2.5 \mathrm{~kg}$ is reported by $29 \%$ children. Every Child was having Immunization card irrespective of the place of delivery. $72 \%$ children having all 3 birth vaccinations: BCG, Hep B and OPV 0 dose with $100 \%$ BCG coverage. All appropriate vaccinations at age of 6 weeks, 10 weeks, and 14 weeks were received by $41 \%, 37 \%$ and $38 \%$ children respectively. $86 \%$ of children have received Measles and Vitamin $A$ at age of 9 months.

\section{Other relevant history}

At time of data collection, $10.7 \%$ children were having history of past illness, $7 \%$ were having history of worm infestation. $40 \%$ were having history of suffering from cough/wheeze/increase Respiratory rate in last 15 days while $26 \%$ children were suffering from fever in last 15 days. $50 \%$ of children approached healthcare provider from Govt. for all these issues (Table 5).

\section{Results}

140 children (55 boys and 85 girls) participated in study and around $40.7 \%$ children were found to be stunted $29.3 \%$ found to have wasting and around $44.3 \%$ were found underweight. Out of 55 males, $30(54.5 \%)$ were underweight, 20 (36.4\%) were stunted and 19 $(34.5 \%)$ were found to be wasted. Out of 85 females, 32 (37.6\%) were underweight, 37 (43.5\%) were stunted and $22(25.9 \%)$ were found to be wasted.

\section{Conclusion}

The findings of the health situation being better than NFHS-4 findings for rural areas (State as well as Bastar) might reflect the changing socioeconomic situation and habits of the tribal population. Relatively lower prevalence of malnutrition in these villages can be attributed to the relatively close location to District Headquarters which ensures better living conditions, educational attainment, extent of land holdings and other sources of earnings, and could access the government services and schemes, which have contributed in the process of economic development of the community.

\begin{tabular}{|c|c|c|c|c|c|c|c|c|}
\hline $\begin{array}{c}\text { Age in } \\
\text { Months }\end{array}$ & & $\begin{array}{c}\text { Total } \\
\text { Sample }\end{array}$ & \multicolumn{2}{|c|}{ Stunting } & \multicolumn{2}{|c|}{ Wasting } & \multicolumn{2}{|c|}{ Underweight } \\
\hline \multirow{3}{*}{$0-12$} & Male & 9 & 4 & $44.40 \%$ & 0 & $0.00 \%$ & 4 & $44.40 \%$ \\
\cline { 2 - 10 } & Female & 26 & 6 & $23.10 \%$ & 11 & $42.30 \%$ & 8 & $30.80 \%$ \\
\cline { 2 - 10 } & Total & 35 & 10 & $28.60 \%$ & 11 & $31.40 \%$ & 12 & $34.30 \%$ \\
\hline \multirow{4}{*}{$13-24$} & Male & 12 & 6 & $50.00 \%$ & 11 & $91.70 \%$ & 9 & $75.00 \%$ \\
\cline { 2 - 10 } & Female & 10 & 7 & $70.00 \%$ & 2 & $20.00 \%$ & 4 & $40.00 \%$ \\
\cline { 2 - 10 } & Total & 22 & 13 & $59.10 \%$ & 13 & $59.10 \%$ & 13 & $59.10 \%$ \\
\hline \multirow{4}{*}{$25-36$} & Male & 13 & 2 & $15.40 \%$ & 2 & $15.40 \%$ & 6 & $46.20 \%$ \\
\cline { 2 - 10 } & Female & 20 & 9 & $45.00 \%$ & 1 & $5.00 \%$ & 7 & $35.00 \%$ \\
\cline { 2 - 10 } & Total & 33 & 11 & $33.30 \%$ & 3 & $9.10 \%$ & 13 & $39.40 \%$ \\
\hline \multirow{3}{*}{$37-48$} & Male & 12 & 4 & $33.30 \%$ & 2 & $16.70 \%$ & 6 & $50.00 \%$ \\
\cline { 2 - 9 } & Female & 12 & 5 & $41.70 \%$ & 6 & $50.00 \%$ & 8 & $66.70 \%$ \\
\cline { 2 - 9 } & Total & 24 & 9 & $37.50 \%$ & 8 & $33.30 \%$ & 14 & $58.30 \%$ \\
\hline \multirow{3}{*}{$49-60$} & Male & 9 & 4 & $44.40 \%$ & 4 & $44.40 \%$ & 5 & $55.60 \%$ \\
\cline { 2 - 9 } & Female & 17 & 10 & $58.80 \%$ & 2 & $11.80 \%$ & 5 & $29.40 \%$ \\
\cline { 2 - 9 } & Total & 26 & 14 & $53.80 \%$ & 6 & $23.10 \%$ & 10 & $38.50 \%$ \\
\hline \multirow{3}{*}{ Total } & Male & 55 & 20 & $36.40 \%$ & 19 & $34.50 \%$ & 30 & $54.50 \%$ \\
\cline { 2 - 9 } & Female & 85 & 37 & $43.50 \%$ & 22 & $25.90 \%$ & 32 & $37.60 \%$ \\
\cline { 2 - 9 } & & 140 & 57 & $40.70 \%$ & 41 & $29.30 \%$ & 62 & $44.30 \%$ \\
\hline
\end{tabular}

Table 5: Percentage of stunting, wasting and underweight in study population. Key performance Indicators

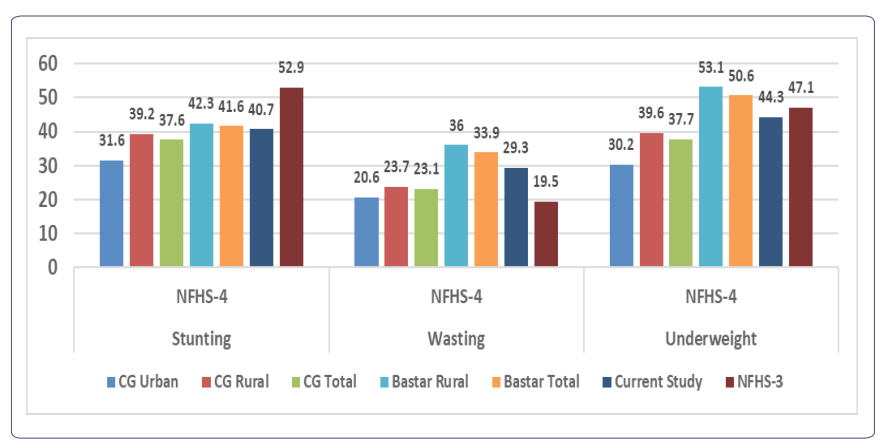

The present study confirms that despite several nutrition programmes, the extent of undernutrition has remained high in the children living in predominantly tribal rural areas of Bastar Region. As the main underlying cause of undernutrition among the tribal children is the poor socioeconomic conditions of the tribal population, there is a need for a multi-pronged strategy for redressing this problem.

Aside from increasing the budgetary allocation for nutrition specific interventions, the state needs to ensure appropriate usage of funds. In addition, there is an urgent need to tighten the implementation mechanism of the Public Distribution System (PDS) in the tribal areas of Bastar. The department of Civil Supplies (food security) must ensure that tribal families are not deprived of the ration that they are entitled to because of issues like non-possession of card. Besides that, State should seriously consider providing other nutritious food items through PDS in the tribal areas so that the nutritional needs of the tribal children and adults are met, and the problem of micronutrient deficiencies is effectively addressed.

Aside from improving socioeconomic conditions of the tribal population, there is a need to improve the child care and feeding practices. 
Citation: Sinha T, Singh G, Nag U (2019) Nutritional Status of Children Under 5 Years in Tribal Villages of Bastar Chhattisgarh India. J intern Med Prim Healthcare 3: 007.

The positive breastfeeding practices related to exclusive breastfeeding during the first half of infancy and continued breastfeeding through the second year of life and beyond encountered in the population should be strongly promoted. Practices that require attention are the delay in introduction of complementary foods and the low dietary diversity. This should be addressed by providing education about child care and feeding practices to women from time they become pregnant.

In the current study, the prevalence of undernutrition was found to be associated with children's age, their health status, family size and ethnicity. The older children seemed to be at a relatively higher risk of stunting and underweight, but they were found to have lower odds of wasting than the younger children. Children who were weaned much later ( 10 months or more) than the recommended age of 4 to 6 months were significantly less likely to be stunted. This implies that despite weaning at the recommended age, those children did not receive the necessary nutrition through the complementary feeds and missed out on the nutrition available through breast milk.

Having sickness episode was another risk factor of undernutrition. Children who did not suffer from any disease like Diarrhoea, cold or any other acute illness were significantly less likely to be underweight. The result was consistent with previous studies that malnourished children would be more prone to sickness or sick children would tend to be underweight, thus confirming the two-way relationship between undernutrition and health [22,23].

Children living in larger households with more than 6 members (and hence, most likely to be in multigenerational households) were more likely to be stunted or underweight than those from smaller families with not more than 5 members. A high prevalence of stunting among the children living in larger households was also documented by other studies [24]. Inadequate availability of food and inequality in the intra-household distribution of food may possibly explain the reason behind the higher prevalence of undernutrition in larger households.

\section{Recommendations}

Reduction of malnutrition in 0-5 age group can be ensured by availability of supplementary feed. Healthcare providers to focus on health education among parents, especially the mothers on the exact nutritional requirements in terms of quality and quantity of the child at specific age groups. A further evaluation of the problem of the tribes needs to be done, using a mixed methods approach to understand issues related to not only health, but also social development and integration.

\section{Conflict of Interest: Nil}

\section{Funding: Nil}

\section{References}

1. Hoddinott J, Alderman H, Behrman JR, Haddad L, Horton S, et al. (2013) The economic rationale for investing in stunting reduction. Matern Child Nutr 2:69-82.

2. Malnutrition. UNICEF DATA.
3. Black RE, Victora CG, Walker SP, Bhutta ZA, Christian P, et al. (2013) Maternal and child undernutrition and overweight in low-income and middle-income countries. Lancet 382: 427-451.

4. Fenske N, Burns J, Hothorn T, Rehfuess EA (2013) Understanding child stunting in India: A comprehensive analysis of socio-economic, nutritional and environmental determinants using additive quantile regression. PLoS One 8: 78692 .

5. Census of India (2011) Provisional Population Tables.

6. (2011) Census of India: Provisional Population Tables.

7. Nourishing India's Tribal Children.

8. Rapid Survey on Children (RSOC) 2013-14

9. Bansal RD, Mehra M (1999) Malnutrition: a silent emergency. Indian J Public Health 43: 1-2.

10. Park K (2005) Park's Textbook of Preventive and Social Medicine. $\left(18^{\text {th }}\right.$ edn), Banarasidas Bhanot Publishers, Jabalpur, 405.

11. Bloss E, Wainaina F, Bailey RC (2004) Prevalence and Predictors of Underweight, Stunting, and Wasting among Children Aged 5 and Under in Western Kenya. J Trop Pediatr 50: 260-270.

12. Agarwal V (2005) Integrated Management of Neonatal and Childhood Illness: Continuing Medical Education Module Public Health Department. 6-8.

13. K Park (2005) Park's Textbook of Preventive \& Social Medicine. $\left(18^{\text {th }}\right.$ edn), Bhanot Publishers, Jabalpur, India, 406.

14. UNICEF (2006) Progress for Children. A report card on Nutrition UNICEF: Times of India.

15. Chakraborty S, Gupta SB, Chaturvedi SK (2006) A Study of Protein Energy Malnutrition (PEM) in Children (0 to 6 Year) in a Rural Population of Jhansi District (U.P.). Indian Journal of Community Medicine 31: 291292.

16. Gupta VM, Shukla KK (1992) Epidemiological correlates of Protein Energy Malnutrition in pre-school children. Ind J Prev Soc Med 23: 26-32.

17. Kumar P (1993) Social Classification need for constant Upgrading. Ind J Comm Med 18: 60-61.

18. Waterlow IC, Buzina R, Keller W, Lane IM, Nichaman MZ, et al. (1977) The presentation and use of height and weight data for comparing the nutritional status of groups of children under the age of 10 years. Bull World Health Organ 55: 489-498.

19. Kuczmarski RJ, Ogden CL, Guo SS, Grummer-Strawn LM, Flegal KM, et al. (2002) 2000 CDC Growth Charts for the United States: methods and development. Vital Health Stat 11: 1-190.

20. WHO (1995) Physical status: the use and interpretation of anthropometry, WHO Technical Report Series pg. No: 854.

21. https://en.wikipedia.org/wiki/Swachh_Bharat_mission.

22. Danbe D, Taye A (2015) Nutritional status of under-five children in Hawassa Zuria District, Southern Ethiopia. American Journal of Health Research 3: 286-292.

23. Abera L, Dejene T, Laelago T (2017) Prevalence of malnutrition and associated factors in children aged 6-59 months among rural dwellers of damot gale district, south Ethiopia: community based cross sectional study. Int J Equity Health 16: 111.

24. Pal A, Pari AK, Sinha A, Dhara PC (2017) Prevalence of undernutrition and associated factors: A cross-sectional study among rural adolescents in West Bengal, India. Int J Pediatr Adolesc. 4: 9-18. 
Citation: Sinha T, Singh G, Nag U (2019) Nutritional Status of Children Under 5 Years in Tribal Villages of Bastar Chhattisgarh India. J intern Med Prim Healthcare 3: 007.

- Page 6 of 6 - 


\section{II}

Journal of Anesthesia \& Clinical Care

Journal of Addiction \& Addictive Disorders

Advances in Microbiology Research

Advances in Industrial Biotechnology

Journal of Agronomy \& Agricultural Science

Journal of AIDS Clinical Research \& STDs

Journal of Alcoholism, Drug Abuse \& Substance Dependence

Journal of Allergy Disorders \& Therapy

Journal of Alternative, Complementary \& Integrative Medicine

Journal of Alzheimer's \& Neurodegenerative Diseases

Journal of Angiology \& Vascular Surgery

Journal of Animal Research \& Veterinary Science

Archives of Zoological Studies

Archives of Urology

Journal of Atmospheric \& Earth-Sciences

Journal of Aquaculture \& Fisheries

Journal of Biotech Research \& Biochemistry

Journal of Brain \& Neuroscience Research

Journal of Cancer Biology \& Treatment

Journal of Cardiology: Study \& Research

Journal of Cell Biology \& Cell Metabolism

Journal of Clinical Dermatology \& Therapy

Journal of Clinical Immunology \& Immunotherapy

Journal of Clinical Studies \& Medical Case Reports

Journal of Community Medicine \& Public Health Care

Current Trends: Medical \& Biological Engineering

Journal of Cytology \& Tissue Biology

Journal of Dentistry: Oral Health \& Cosmesis

Journal of Diabetes \& Metabolic Disorders

Journal of Dairy Research \& Technology

Journal of Emergency Medicine Trauma \& Surgical Care

Journal of Environmental Science: Current Research

Journal of Food Science \& Nutrition

Journal of Forensic, Legal \& Investigative Sciences

Journal of Gastroenterology \& Hepatology Research

Journal of Gerontology \& Geriatric Medicine
Journal of Genetics \& Genomic Sciences

Journal of Hematology, Blood Transfusion \& Disorders

Journal of Human Endocrinology

Journal of Hospice \& Palliative Medical Care

Journal of Internal Medicine \& Primary Healthcare

Journal of Infectious \& Non Infectious Diseases

Journal of Light \& Laser: Current Trends

Journal of Modern Chemical Sciences

Journal of Medicine: Study \& Research

Journal of Nanotechnology: Nanomedicine \& Nanobiotechnology

Journal of Neonatology \& Clinical Pediatrics

Journal of Nephrology \& Renal Therapy

Journal of Non Invasive Vascular Investigation

Journal of Nuclear Medicine, Radiology \& Radiation Therapy

Journal of Obesity \& Weight Loss

Journal of Orthopedic Research \& Physiotherapy

Journal of Otolaryngology, Head \& Neck Surgery

Journal of Protein Research \& Bioinformatics

Journal of Pathology Clinical \& Medical Research

Journal of Pharmacology, Pharmaceutics \& Pharmacovigilance

Journal of Physical Medicine, Rehabilitation \& Disabilities

Journal of Plant Science: Current Research

Journal of Psychiatry, Depression \& Anxiety

Journal of Pulmonary Medicine \& Respiratory Research

Journal of Practical \& Professional Nursing

Journal of Reproductive Medicine, Gynaecology \& Obstetrics

Journal of Stem Cells Research, Development \& Therapy

Journal of Surgery: Current Trends \& Innovations

Journal of Toxicology: Current Research

Journal of Translational Science and Research

Trends in Anatomy \& Physiology

Journal of Vaccines Research \& Vaccination

Journal of Virology \& Antivirals

Archives of Surgery and Surgical Education

Sports Medicine and Injury Care Journal

International Journal of Case Reports and Therapeutic Studies

Journal of Ecology Research and Conservation Biology

Submit Your Manuscript: http://www.heraldopenaccess.us/Online-Submission.php 